\title{
OBSERVATIONS UPON THE WITHDRAWAL OF SODIUM CHLO- RIDE FROM THE DIET IN HYPERTENSIVE AND NORMOTENSIVE INDIVIDUALS
}

\author{
BY REATA RENWICK, J. S. ROBSON, AND C. P. STEWART
}

(From the Department of Clinical Chemistry, University of Edinburgh, Edinburgh, Scotland)

(Submitted for publication January 12, 1955 ; accepted March 2, 1955)

The mechanism by which the kidney conserves sodium and chloride in the face of a suddenly diminished dietary intake has been the subject of much investigation (1-4). The possible importance of defining this mechanism more adequately was emphasized by the claim that in hypertensive subjects the response to dietary salt withdrawal differs from the response in normal subjects. Perera and Blood (5) suggested that the kidneys of hypertensive subjects are capable of retaining salt more efficiently than the kidneys of individuals with normal blood pressures (either as a result of primary renal changes or of changes mediated by the adrenal cortex), and this has been interpreted as evidence that the adrenal cortex in hypertensive subjects is abnormal with regard to the hormone or hormones which influence the renal tubular reabsorption of salt (6). We have attempted to detect an adrenal response to a decrease in sodium intake and the results are reported elsewhere (7). This provided an opportunity for re-investigating, in normotensive and hypertensive subjects, other aspects of the response to sudden and almost complete withdrawal of sodium chloride from the diet. In view of the figures reported by Perera and Blood (5), observations were made on the change in body weight and volume of urine excreted in the first twenty-four-hour periods after salt withdrawal. Changes in the urinary excretion of sodium, potassium, chloride, and nitrogen under these conditions were estimated. A few estimations of the fecal excretion of sodium, potassium, and nitrogen were also carried out.

\section{Subjects}

Six normotensive and six hypertensive hospital patients were used in this study. The former included four patients who had been admitted for relatively trivial complaints (i.e., hemorrhoids, mild upper respiratory infection, dyspepsia, prolapse of intervertebral disc producing mild sciatica) and who had recovered prior to the period of investigation, and two subjects who were not suffering from any disease, and in whom there was no known family history of hypertension. The relevant clinical data of these subjects are given in Table I with similar data for the hypertensive cases. These latter subjects were patients in whom essential hypertension had been found either incidentally in the course of a general physical examination or who had been referred to hospital for insomnia or headaches. All subjects were within the range for ideal weight as given by the Metropolitan Life Insurance Company. No evidence of heart failure or other disease process was present in any subject and renal function, as tested by the capacity to dilute and concentrate urine maximally and by estimation of glomerular filtration rate using the clearance of inulin or creatinine, was within normal limits. Protein was not detected in the urine of any subject and the blood urea nitrogen was normal in all cases. The ages of both the hypertensive and normotensive groups were comparable and the sex distribution was similar.

\section{Diet}

All subjects were fed a completely constant diet throughout the period of investigation. This con-

TABLE I

Relevant clinical data

\begin{tabular}{|c|c|c|c|c|}
\hline \multirow[b]{2}{*}{$\begin{array}{l}\text { Case } \\
\text { No. }\end{array}$} & \multirow[b]{2}{*}{$\begin{array}{l}\text { Age } \\
\text { Yrs. }\end{array}$} & \multirow[b]{2}{*}{ Sex } & \multicolumn{2}{|c|}{$\begin{array}{c}\text { Mean blood pressure with range of } \\
\text { daily observations taken over } 7 \\
\text { to } 10 \text { days during period } \\
\text { with salt supplement }\end{array}$} \\
\hline & & & $\begin{array}{l}\text { Systolic } \\
\mathbf{m m} . \mathbf{H}_{\mathbf{g}}\end{array}$ & $\begin{array}{c}\text { Diastolic } \\
\mathbf{m m} . \mathrm{HE}_{\mathbf{B}}\end{array}$ \\
\hline \multicolumn{5}{|c|}{ Hypertensive subjects } \\
\hline $\begin{array}{l}1 \\
2 \\
3 \\
4 \\
5 \\
6\end{array}$ & $\begin{array}{l}49 \\
43 \\
40 \\
43 \\
40 \\
46\end{array}$ & $\begin{array}{l}\mathbf{F} \\
\mathbf{F} \\
\mathbf{M} \\
\mathbf{M} \\
\mathbf{F} \\
\mathbf{M}\end{array}$ & $\begin{array}{l}220 \pm 15 \\
205 \pm 15 \\
152 \pm 8 \\
169 \pm 10 \\
160 \pm 10 \\
167 \pm 13\end{array}$ & $\begin{array}{l}128 \pm 13 \\
110 \pm 5 \\
110 \pm 7 \\
103 \pm 8 \\
108 \pm 5 \\
105 \pm 10\end{array}$ \\
\hline \multicolumn{5}{|c|}{ Normal subjects } \\
\hline $\begin{array}{l}1 \\
2 \\
3 \\
4 \\
5 \\
6\end{array}$ & $\begin{array}{l}54 \\
43 \\
35 \\
50 \\
47 \\
34\end{array}$ & $\begin{array}{l}\mathbf{M} \\
\mathbf{F} \\
\mathbf{F} \\
\mathbf{M} \\
\mathbf{F} \\
\mathbf{M}\end{array}$ & $\begin{array}{l}110 \pm 5 \\
137 \pm 8 \\
115 \pm 0 \\
118 \pm 5 \\
130 \pm 5 \\
120 \pm 5\end{array}$ & $\begin{array}{l}65 \pm 5 \\
87 \pm 5 \\
68 \pm 2 \\
67 \pm 5 \\
80 \pm 5 \\
75 \pm 5\end{array}$ \\
\hline
\end{tabular}


sisted of measured amounts of rice, sugar, salt-free bread, salt-free butter, jam, fruit and fruit juice, tea, drinking water, and one egg daily. Additional protein was provided by giving a fixed amount of Casilan (Glaxo) which is virtually sodium and chloride free. The total amount of food consumed differed from subject to subject according to the weight and size but was constant for each subject from day to day and its caloric value ranged from 1500 to 2500 . Thirty to fifty grams of protein was provided by the Casilan and the total protein content of the diet ranged from 50 to $70 \mathrm{gm}$. per day. The calories in the diet were adequate to maintain weight and all subjects were in nitrogen balance. The daily intake of potassium in such a diet is almost entirely dependent upon the amount and nature of fruit and fruit juice consumed. In order that this should remain constant it was found necessary to keep the type of fruit eaten by the patient the same throughout, and a given batch of canned juice was used for each patient. Batch differences are responsible for variations in the intake of potassium between patients and in three cases in which the intake was low, additional amounts of potassium were given by adding fixed amounts of potassium citrate to the juice (hypertensive case No. 6 and normotensive cases No. 4 and 6). The sodium content of the diet was $8 \mathrm{mEq}$. per day.

\section{Plan of experiments}

During the course of the experiments all subjects were allowed out of bed for toilet purposes and for a few hours in the afternoons. The diet was supplemented by capsules of sodium chloride, 3 to $6 \mathrm{gm}$. of which was eaten throughout each day. This was continued until the excretion of the electrolytes under study in the urine became stabilized, i.e., after 4 to 5 days of the diet. The capsules were omitted from the diet after a stable control period of from 7 to 14 days, the patient continuing to eat the diet until the end of the experiment. Twenty-four-hour collections of urine were analyzed and blood was withdrawn at intervals for analysis. In four cases analysis of fecal electrolytes was done.

\section{Methods}

Serum, urinary and fecal sodium and potassium were measured in a Barclay Flame Photometer using lithium as an internal standard. Chloride was estimated by Van Slyke's method (8) and total urinary nitrogen by the micro-Kjeldahl method. Subjects were weighed in a beam balance accurate to $50 \mathrm{gm}$. prior to breakfast and after micturition.

\section{RESULTS}

\section{Body weight and urine volume}

During the control period of 7 to 14 days the body weight of all subjects showed small day-today variations without any systematic trend in either direction. Changes in body weight after 24 and 48 hours of withdrawal of sodium chloride from the diet of both normal and hypertensive subjects are shown in Table II. The change in the urine volume during the first 24 hours after salt restriction is also shown. The variation in each group is considerable and the data overlap to a large extent in the two groups. The absolute fall in weight for the normal subjects ranges from 0.10 to $0.60 \mathrm{Kg}$. ( 0.13 to 0.83 per cent of body weight) and for hypertensive subjects the weight loss ranges from 0 to $0.35 \mathrm{Kg}$. ( 0 to 0.43 per cent body weight). The mean changes are not significantly different $(P=0.2)$. Relatively comparable and slightly larger losses were observed after 48 hours of salt restriction. Alterations in the volume of urine excreted in the 24 hours after salt restriction are also shown in Table II. The average changes in the two groups, +242 $\mathrm{ml}$. and $+227 \mathrm{ml}$., are not significantly different $(P=0.9)$.

TABLE II

Changes in body weight, $\mathrm{Kg}$., and in urine volume, ml., 24 and 48 hours after salt restriction

\begin{tabular}{|c|c|c|c|c|c|c|c|c|}
\hline \multirow[b]{3}{*}{ Subject } & \multicolumn{4}{|c|}{ Normotensive subjects } & \multicolumn{4}{|c|}{ Hypertensive subjects } \\
\hline & \multicolumn{2}{|c|}{$\begin{array}{c}\text { Absolute body } \\
\text { weight change } \\
\mathbf{K g}_{\mathbf{g}}\end{array}$} & \multirow{2}{*}{$\begin{array}{l}\text { \% Wt. } \\
\text { change } \\
24 \text { hrs. }\end{array}$} & \multirow{2}{*}{$\begin{array}{c}\text { Change } \\
\text { in urine } \\
\text { volume } \\
\text { ml. } \\
24 \mathrm{hrs} .\end{array}$} & \multicolumn{2}{|c|}{$\begin{array}{c}\text { Absolute body } \\
\text { weight change } \\
K \mathrm{Kg} .\end{array}$} & \multirow{2}{*}{$\begin{array}{l}\text { \% Wt. } \\
\text { change } \\
24 \text { hrs. }\end{array}$} & \multirow{2}{*}{$\begin{array}{c}\text { Change } \\
\text { in urine } \\
\text { volume } \\
\text { ml. } \\
24 \mathrm{hrs} .\end{array}$} \\
\hline & 24 hrs. & $48 \mathrm{hrs}$. & & & 24 hrs. & 48 hrs. & & \\
\hline $\begin{array}{l}1 \\
2 \\
3 \\
4 \\
5 \\
6\end{array}$ & $\begin{array}{l}-.25 \\
-.50 \\
-.15 \\
-.10 \\
-.20 \\
-.60\end{array}$ & $\begin{array}{l}-.55 \\
-.80 \\
-.70 \\
-.70 \\
-.70 \\
-.10\end{array}$ & $\begin{array}{l}-.34 \\
-.75 \\
-.36 \\
-.13 \\
-.23 \\
-.83\end{array}$ & $\begin{array}{l}+100 \\
-60 \\
+310 \\
+110 \\
+170 \\
+820\end{array}$ & $\begin{array}{l}-.10 \\
0 \\
-.15 \\
-.10 \\
-.35 \\
-.25\end{array}$ & $\begin{array}{l}-.40 \\
-.20 \\
-.85 \\
-.35 \\
-1.00 \\
-.30\end{array}$ & $\begin{array}{l}-.17 \\
0 \\
-.26 \\
-.21 \\
-.43 \\
-.42\end{array}$ & $\begin{array}{l}+210 \\
+200 \\
-160 \\
+280 \\
+300 \\
+530\end{array}$ \\
\hline Mean & -.30 & -.59 & -.44 & +242 & -.16 & -.52 & -.25 & +227 \\
\hline
\end{tabular}


TABLE III

Urinary excretion of sodium

\begin{tabular}{|c|c|c|c|c|}
\hline $\begin{array}{l}\text { Case } \\
\text { No. }\end{array}$ & $\begin{array}{l}\text { Mean 24-hr. urinary } \\
\text { excretion . Na prior } \\
\text { to salt withdrawal } \\
m E q . / 24 \text { hrs. }\end{array}$ & $\begin{array}{l}\text { Na in urine in } 1 \text { st } \\
24 \text { hrs. after salt } \\
\text { withdrawal as \% of } \\
\text { mean } 24-\mathrm{hr} \text {. excretion } \\
\text { in control period }\end{array}$ & $\begin{array}{c}\text { Number of days over } \\
\text { which urinary excretion } \\
\text { of sodium remained } \\
\text { over } 10 \mathrm{mEq} \text {./day } \\
\text { after salt withdrawal } \\
m E q .\end{array}$ & $\begin{array}{l}\text { Cumulative negative } \\
\text { Na balance after salt } \\
\text { withdrawal as a } \\
\text { result of continued } \\
\text { urinary loss } \\
\text { (more than } 10 \mathrm{mEq} . / \text { day) }\end{array}$ \\
\hline \multicolumn{5}{|c|}{ Hypertensive subjects } \\
\hline $\begin{array}{c}1 \\
2 \\
3 \\
4 \\
5 \\
6 \\
\text { Mean }\end{array}$ & $\begin{array}{r}95.0 \\
78.7 \\
78.2 \\
48.8 \\
80.7 \\
103.6 \\
80.8\end{array}$ & $\begin{array}{l}70.5 \\
97.8 \\
81.8 \\
96.3 \\
43.4 \\
79.2 \\
78.2\end{array}$ & $\begin{array}{r}10 \\
12 \\
8 \\
6 \\
10 \\
7 \\
9\end{array}$ & $\begin{array}{l}162 \\
202 \\
142 \\
104 \\
178 \\
164 \\
159\end{array}$ \\
\hline \multicolumn{5}{|c|}{ Normal subjects } \\
\hline $\begin{array}{c}1 \\
2 \\
3 \\
4 \\
5 \\
6 \\
\text { Mean }\end{array}$ & $\begin{array}{l}81.8 \\
79.9 \\
88.8 \\
87.5 \\
99.9 \\
89.7 \\
87.9\end{array}$ & $\begin{array}{r}74.3 \\
90.1 \\
63.5 \\
118.4 \\
83.2 \\
86.5 \\
86.0\end{array}$ & $\begin{array}{r}9 \\
8 \\
4 \\
5 \\
4 \\
10 \\
7\end{array}$ & $\begin{array}{r}236 \\
188 \\
61 \\
215 \\
130 \\
396 \\
204\end{array}$ \\
\hline
\end{tabular}

\section{Electrolytes}

Urinary sodium: Following the withdrawal of salt from the diet, the amount of sodium and chloride excreted in the urine rapidly diminished over the ensuing few days until it reached a level of below $10 \mathrm{mEq}$. per day. Thereafter the body was in only slight negative sodium balance as a result of continued small losses of sodium in the feces, sweat, and urine. The response to withdrawal of salt from the diet in the two groups of subjects is compared in Table III, in which consideration is given to three points, namely 1 ) the amount of sodium remaining in the urine during the first twenty-four hours after withdrawal of salt, 2) the number of days over which the urinary excretion remained above $10 \mathrm{mEq}$. per day and, 3 ) the total sodium deficit which developed as a result of continued urinary excretion during the days of marked negative balance following salt withdrawal. In this way the speed (and efficiency) with which the kidney responds to the sudden change in sodium intake is directly compared in the normotensive and hypertensive subjects.

It is seen that the mean urinary excretion of sodium prior to salt withdrawal is comparable in the two groups. Although there is some individual variation, the average figures for the three criteria for the normotensive and hypertensive subjects are not significantly different. After twenty-four hours of salt restriction, the average excretion of sodium in the urine fell to 78 per cent and 86 per cent of the amount excreted in the control period for the hypertensive and normotensive groups, respectively. The twenty-four-hour urinary loss of sodium was reduced to 5 to $10 \mathrm{mEq}$. in an average of nine days by the hypertensive subjects and in an average of seven days by the normotensive subjects after dietary salt restriction. These figures are not significantly different. The total cumulative negative sodium balance which developed as a result of continued urinary loss in that time averaged $159 \mathrm{mEq}$. for the hypertensive subjects and $204 \mathrm{mEq}$. for the normotensive cases. This difference is not statistically significant $(P=$ 0.3 ).

Urinary chloride: Similar and nearly identical figures were obtained from estimations of urinary chloride in both groups and when they were analyzed in a similar way no marked difference was detectable between the two groups. It is of interest that calculations of water loss based upon total chloride deficits and serum concentrations, and assuming the losses of electrolytes to be extracellular, account for 60 to 100 per cent of the body weight loss over the period. 


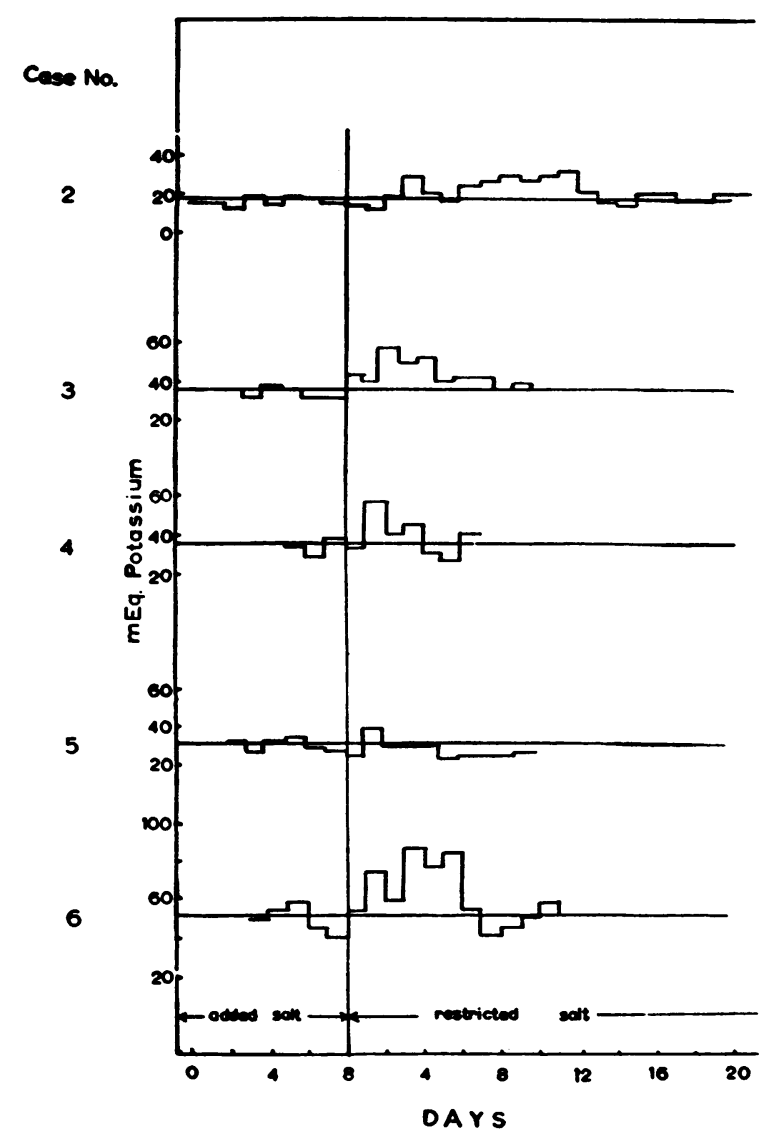

Fig. 1. Normotensive Subjects-Twenty-Four-Hour Urinary Excretion of Potassium Prior to and Following the Withdrawal of Salt from the Diet Which Was Kept Constant in all Other Respects

The horizontal line represents the mean excretion during the control period.

Urinary potassium: Following the withdrawal of salt from the diet and during the time when the urinary excretion of sodium was rapidly diminishing, a temporary increase in the excretion of potassium in the urine in both normal and hypertensive subjects was regularly noted. The increase was maximal about the time when the amount of urinary sodium was approaching 10 $\mathrm{mEq}$. per L. but its time of onset and its duration varied from individual to individual. Figures 1 and 2 illustrate these changes in urinary excretion and Table IV provides a summary of the data for five normal and six hypertensive subjects studied in this way. The number of days over which the excess potassium was detected in the urine and the total cumulative increase in urinary potassium, which represents negative potassium balance, are given. Although the variation from case to case is considerable, no subject was observed in whom an increase in urinary potassium was not seen and no significance can be attached to the slight differences in the mean figures for the two groups of cases. The average urinary potassium excretion in both groups is comparable and the average total cumulative potassium loss as a result of increased urinary excretion amounts to $77 \mathrm{mEq}$. for the hypertensive subjects and $62 \mathrm{mEq}$. for the normotensive cases.

Serum electrolytes: Repeated estimations of the concentration of serum sodium, chloride, and potassium and of the packed cell volume prior to restriction of sodium chloride and for 30 days after its withdrawal did not reveal significant alterations.

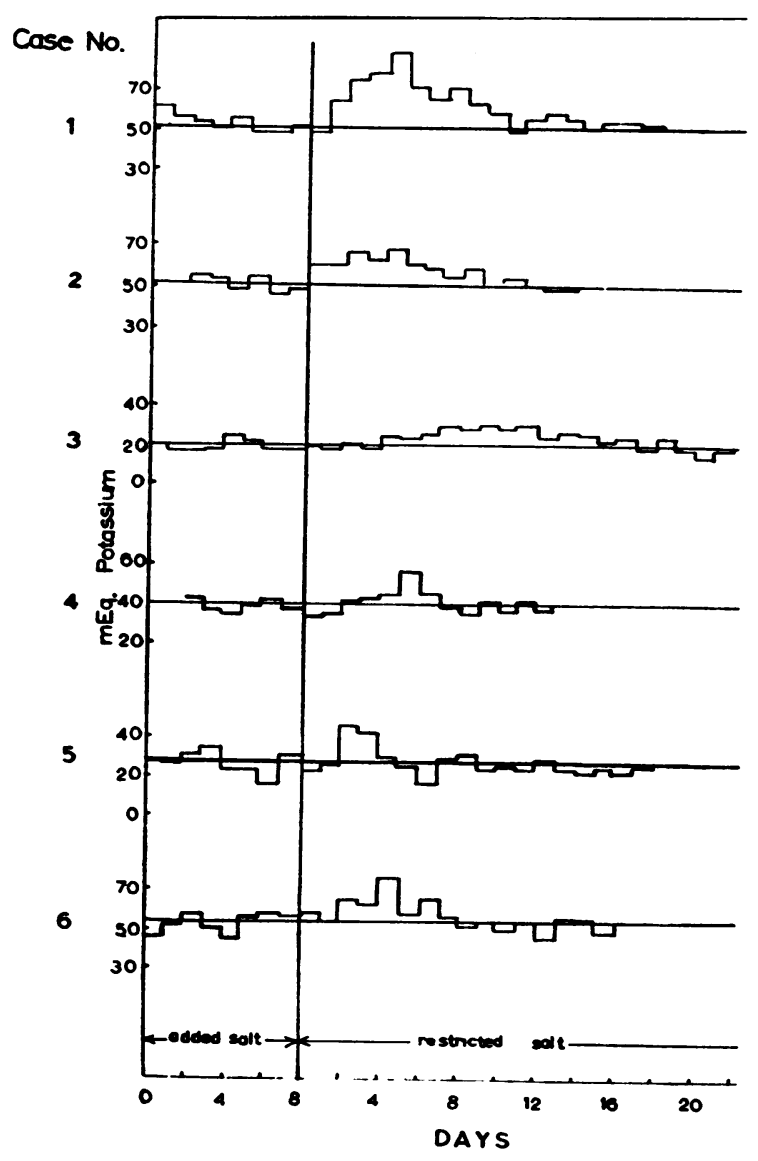

Fig. 2. Hypertenstve Subjects-Twenty-Four-Hour Urinary Excretion of Potassium Prior to and Following the Withdrawal of Salt from the Diet Which Was Kept Constant in all Other Respects

The horizontal line represents the mean excretion during the control period. 
TABLE IV

Urinary excretion of potassium

\begin{tabular}{|c|c|c|c|}
\hline $\begin{array}{l}\text { Case } \\
\text { No. }\end{array}$ & $\begin{array}{c}\text { Mean } \\
\text { 24-hour } \\
\text { K excre- } \\
\text { tion prior } \\
\text { to galt } \\
\text { withdrawal } \\
\text { wiRg. } / 24 \text { hrs. }\end{array}$ & $\begin{array}{c}\text { Total cumula- } \\
\text { tive } \mathbf{K} \text { loss } \\
\text { during negative } \\
\mathbf{K} \text { balance } \\
\text { after salt } \\
\text { withdrawal } \\
\text { mEq. }\end{array}$ & $\begin{array}{l}\text { Days after } \\
\text { salt withdrawal } \\
\text { during which } \\
\text { negative } K \\
\text { balance } \\
\text { occurred }\end{array}$ \\
\hline \multicolumn{4}{|c|}{ Hypertensive subjects } \\
\hline $\begin{array}{c}1 \\
2 \\
3 \\
4 \\
5 \\
6 \\
\text { Mean }\end{array}$ & $\begin{array}{l}51 \\
20 \\
52 \\
39 \\
28 \\
52 \\
40\end{array}$ & $\begin{array}{r}162 \\
84 \\
86 \\
33 \\
43 \\
56 \\
77\end{array}$ & $\begin{array}{l}\text { 2nd-10th } \\
\text { 5th-18th } \\
1 \text { st - 9th } \\
3 \text { rd - 7th } \\
3 \text { rd - 4th } \\
1 \text { st - 7th } \\
2 \text { nd }-9 \text { th }\end{array}$ \\
\hline \multicolumn{4}{|c|}{ Normal subjects } \\
\hline $\begin{array}{c}1 \\
2 \\
3 \\
4 \\
5 \\
6 \\
\text { Mean }\end{array}$ & $\begin{array}{l}\overline{18} \\
36 \\
36 \\
31 \\
52 \\
35\end{array}$ & $\begin{array}{r}-60 \\
94 \\
37 \\
8 \\
113 \\
62\end{array}$ & $\begin{array}{l}\text { 7th-12th } \\
1 \text { st }-9 \text { th } \\
\text { 2nd- } 4 \text { th } \\
\text { 2nd } \\
1 \text { st - 6th } \\
3 \text { rd - 7th }\end{array}$ \\
\hline
\end{tabular}

Fecal electrolytes: The fecal excretion of sodium, potassium, and chloride was determined in only four cases for a few days in the control period and after salt restriction. The excretion by this route was small in relation to the urinary losses and as might be expected, was not influenced by salt restriction.

Nitrogen: No consistent or significant alteration in the urinary excretion of nitrogen in the urine was observed throughout the control period or during the phase of negative sodium or potassium balance in any of the twelve subjects. The day-today variation in nitrogen excretion in any individual case was small and any appreciable change related to the alterations in electrolyte balance could have been detected. The significance of this constancy is discussed in relation to the alterations in potassium balance below.

\section{DISCUSSION}

The results obtained by Perera and Blood (5) appeared to establish the existence of a very clear difference in the response of normotensive and hypertensive subjects to salt withdrawal. This difference took the form of a significantly smaller fall in weight on the part of the hypertensives in the first twenty-four hours after withdrawal of salt from the diet and was associated with a smaller total twenty-four-hour urinary volume. It seemed likely that such differences in weight occurring acutely after salt withdrawal were due to alteration in water and salt content of the body, and Perera and Blood stated that "calculation of sodium and chloride clearances in two control subjects and two hypertensive patients showed little change in the non-hypertensive individual following salt restriction but a definite reduction in clearance values in patients with elevated blood pressure." Our results show that there is considerable individual variation in the weight and urinary volume changes during the first twentyfour and forty-eight hours after the withdrawal of salt but that there is no consistent difference between the normotensive and hypertensive groups. This occurred in spite of the rigid control of dietary intake and uniformity of the conditions under which the experiments were conducted. It is possible that the number of cases studied from this point of view is too small to demonstrate any slight difference that might exist between such groups. The results obtained by Thomas, Howard, and Isaacs (9) with 83 medical students suggest that this might be the case, though their results are difficult to interpret because of the absence of control hypertensive subjects of comparable age. It is reasonable to conclude, however, from both our own results and those of Thomas, Howard, and Isaacs that any difference in response, if it exists at all, is slight.

The response in relation to the immediate reduction in the urinary excretion of sodium chloride, the total sodium chloride deficit and the number of days required to establish near sodium balance in the two groups is a more reliable demonstration of the close similarity in behaviour in hypertensive and normotensive subjects. These observations over several days are likely to be more accurate than total body weight changes in twenty-four hours, and if the latter possess any physiological significance it is likely to be revealed in such observations. The similarity in the response as judged by these studies lends no support to the view that the hypertensive subject reacts very differently from the normal. In view of the fact that the serum sodium and chloride concentrations show no detectable alteration within the first 14 days of salt restriction, the present data do not support the idea that the re- 
nal clearance of sodium or chloride is significantly different in the two groups, as suggested by Perera and Blood, on the basis of studies in two cases. In addition, and contrary to the observations of these workers, none of our subjects complained of symptoms suggestive of salt depletion throughout, the entire experimental period. A possible explanation of the differences between our results and those of Perera and Blood may perhaps be found in our more rigid control of salt intake before the period of salt deprivation. We found that the urinary excretion of electrolytes and nitrogen became stable after a period of 4 to 5 days of the diet and a further control period of 7 to 14 days was then undertaken before withdrawing salt. The cases studied by Perera and Blood were given the experimental diet for only two days prior to salt restriction. It is evident from the data of these authors that only five out of eleven subjects in which it is possible to make any estimate of balance were, in point of fact, in chloride balance on the day prior to salt withdrawal. Three out of four of the normal subjects excreted chloride in the urine considerably in excess of estimated intake while three out of seven hypertensive subjects excreted considerably less chloride in the urine than was ingested, no hypertensive subject apparently being in negative balance. Furthermore, the published data are not consistent with the statement that no change in the clearance of chloride occurs in the hypertensive subjects since, in the absence of any change in serum concentrations, constancy of clearance would only result from constancy in chloride excretion after salt restriction, and the data do not show such constancy.

The dangers of interpreting observed differences in the rate of salt or water excretion or in body weight changes in terms of abnormal adrenocortical activity are considerable. It is possible that, among other factors, minimal and sub-clinical degrees of cardiac insufficiency might alter the response to salt withdrawal in ambulant subjects in the direction observed by Perera and Blood. On the other hand, it is difficult to visualize factors operating to obliterate any such difference if it has physiological reality.

The existence of a period of negative potassium balance following the withdrawal of salt from the diet has been the subject of controversy and its existence would afford circumstantial evidence of an adrenal response. Black, Platt, and Stanbury (1) were unable to confirm the presence of an increase in urinary potassium to a level higher than the intake, such as was noted by Leaf and Couter (3) in three hypertensive subjects following salt withdrawal, and they considered this to be evidence against the view that a DOC-like substance acted to conserve salt under such conditions. The magnitude of the potassium loss, however, in the subjects we have investigated is such that its existence would escape notice unless there was rigid control of potassium and nitrogen intake throughout the control and experimental period. It seems likely that the failure to observe this loss in the experiments of Black, Platt, and Stanbury is due to the fact that the patients were in negative nitrogen balance and that their consumption of the modified rice diet was admittedly not kept rigidly constant. Although, in our own experiments, there was some variation in the duration and magnitude of the increased urinary potassium loss, it was greatest where the urinary sodium loss was approaching minimal values and when the subject had nearly re-established sodium balance. After this the urinary potassium loss subsided and the subjects returned to the state of potassium balance. Since no increase in the urinary excretion of nitrogen was detected during the phase of increased potassium loss in the urine the latter cannot be ascribed to body tissue breakdown. Estimations of the rate of glomerular filtration carried out at intervals before and after salt restriction in those subjects have not been reported in detail for they do not help to solve the problem of the mechanism of salt conservation in the face of restricted intake. Taken in conjunction, however, with the evidence for increased tubular reabsorption of salt in such circumstances presented by Black, Platt, and Stanbury, the coincidence of increased potassium urinary loss, unattended by an increase in nitrogen excretion, with marked diminution of sodium and chloride in the urine is consistent with the view that the two phenomena could be due to increased activity or secretion of a salt retaining hormone of the adrenal glands. This view is in agreement with that of Leaf and Couter (3) and has recently received direct support from the work of Luetscher and Johnson on aldosterone (4). 
The fact that the increase in the urinary excretion of potassium under these conditions is temporary deserves comment. It does not necessarily mean that the increased adrenocortical activity, suggested as being indicated by this, is temporary for it has been shown in man that the administration of adrenocorticotrophic hormone, cortisone and desoxycorticosterone acetate produces little or no urinary potassium loss when the sodium intake has been restricted $(10,11)$. Evidence to be presented elsewhere, however, suggests that there is a temporary increase in the excretion of adrenocorticoids roughly coincident with the period of potassium loss (7).

\section{SUMMARY}

1. Observations have been made upon the change in body weight, urinary volume and the urinary excretion of sodium, potassium, chloride, and nitrogen in hypertensive and normal subjects following sudden and virtually complete dietary restriction of sodium chloride.

2. During the first 24 and 48 hours of salt deprivation, body weight decreased in all subjects. This decrease was not significantly different in hypertensive and normal subjects.

3. Following the withdrawal of sodium chloride from the diet, the rates at which the urinary excretion of sodium and chloride decreased and the total body deficit of sodium and chloride resulting from continued urinary loss were not significantly different in the two groups of subjects. These observations on a small number of cases support the view that any difference which might be present between the two groups is so small as to be of no significance.

4. After the withdrawal of sodium chloride from the diet and during the time when the urinary excretion of sodium was rapidly diminishing a temporary increase in the excretion of potassium in the urine in hypertensive and normal subjects was regularly noted. This was not associated with an increase in the excretion of urinary nitrogen.

5. It seems reasonable to interpret this observation as indicating an increase in adrenocortical activity in immediate response to withdrawal of salt from the diet.

\section{ACKNOWLEDGMENTS}

The authors are greatly indebted to the Medical Research Council for grants which made it possible for R. R. to take part in the investigations, and to the dietetic staff of Ward 21, Royal Infirmary, Edinburgh, for their co-operation.

\section{REFERENCES}

1. Black, D. A. K., Platt, R., and Stanbury, S. W., Regulation of sodium excretion in normal and salt-depleted subjects. Clin. Sc., 1950, 9, 205.

2. Daughaday, W. H., and MacBryde, C. M., Renal and adrenal mechanisms of salt conservation: The excretion of urinary formaldehydogenic steroids and 17-ketosteroids during salt deprivation and desoxycorticosterone administration. J. Clin. Invest., 1950, 29, 591.

3. Leaf, A., and Couter, W. T., Evidence that renal sodium excretion by normal human subjects is regulated by adrenal cortical activity. J. Clin. Invest., 1949, 28, 1067.

4. Luetscher, J. A., Jr., and Johnson, B. B., Observations on the sodium-retaining corticoid (aldosterone) in the urine of children and adults in relation to sodium balance and edema. J. Clin. Invest., 1954, 33, 1441.

5. Perera, G. A., and Blood, D. W., Disturbance in salt and water metabolism in hypertension. Am. J. Med., 1946, 1, 602.

6. Perera, G. A., The adrenal cortex and hypertension. Bull. New York Acad. Med., 1950, 26, 75.

7. Renwick, R., Robson, J. S., and Stewart, C. P., Observations upon the withdrawal of sodium from the diet. In preparation.

8. Van Slyke, D. D., The determination of chlorides in blood and tissues. J. Biol. Chem., 1923, 58, 523.

9. Thomas, C. B., Howard, E., and Isaacs, A., The effect of sodium withdrawal upon the body weight of normal young men. Bull. Johns Hopkins Hosp., 1949, 85, 115.

10. Relman, A. S., and Schwartz, W. B., The effect of DOCA on electrolyte balance in normal man and its relation to sodium chloride intake. Yale J. Biol. \& Med., 1952, 24, 540.

11. Seldin, D. W., Welt, L. G., and Cort, J., The effect of pituitary and adrenal hormones on the metabolism and excretion of potassium. J. Clin. Invest., 1951, 30, 673. 